\title{
A szénfelület kémiai tulajdonságainak szerepe az anyagtudományban. A Schay-Nagy izotermaegyenlettől a redukált grafén-oxidig
}

\author{
DOMÁN Andrea, ÁBRAHÁM Dániel, NAGY Balázs, LÁSZLÓ Krisztina* \\ Fizikai Kémia és Anyagtudományi Tanszék, Budapesti Müszaki és Gazdaságtudományi Egyetem, \\ 1521 Budapest, Magyarország
}

\section{Bevezetés}

Hosszú ideig a pórusos szeneket „csak” általános szorbensnek tekintették, mivel szorpciós tulajdonságaik egyértelmüen kapcsolatosak a szük pórusokban kialakuló nagy potenciálgödörrel. Ezért a gáz vagy folyadék fázisból az adszorptívum molekula kémiai tulajdonságaitól függetlenül minden, a pórusokhoz hozzáférni képes molekulát megkötnek. Ezen tulajdonságuknak köszönhetően széleskörű alkalmazásuk pl. a víztisztításban, gázelválasztásban, az élelmiszeriparban és gyógyszerként is töretlen és emelkedik. A felületkémia szerepére egyrészt a folyadékelegyekből történő adszorpció elsősorban alapkutatás jellegü felismerései utaltak (1. ábra). A Schay Géza, Nagy Lajos György nevével fémjelezhető hazai adszorpciós iskola eredményei ${ }^{1,2}$ már a 60 -as években rámutattak arra, hogy a kémiai tulajdonságok által meghatározott felületi kölcsönhatások jelentős szerepet játszanak az oldatfázisból a pórusos szenek felületén kialakuló adszorbeált rétegek összetételének kialakításában.

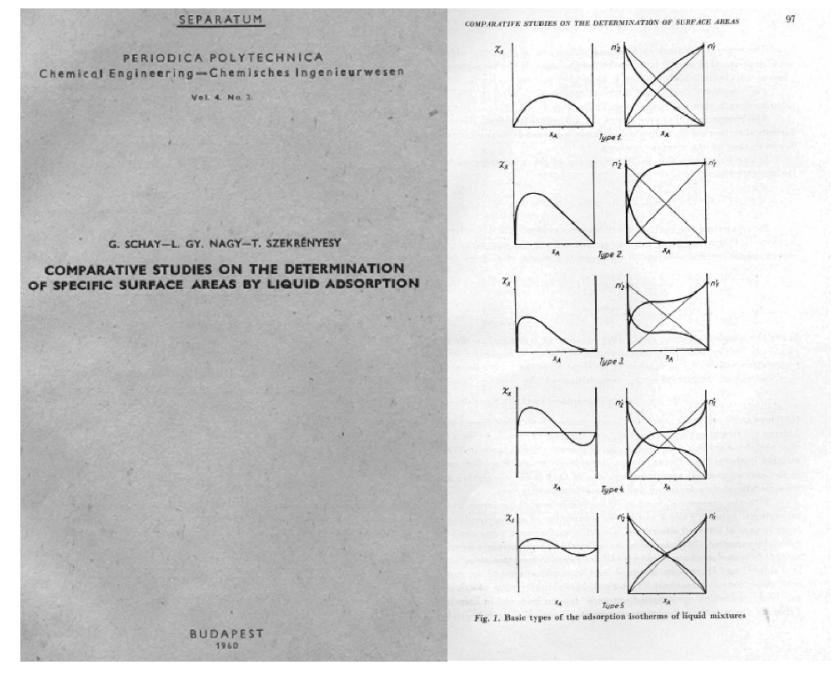

1. Ábra A Schay-Nagy féle izotermaeloszlás első közlése a BME Periodica Polytechnica Chemical Engineering lapjában ${ }^{1}$

Más makroszkopikus jelenségeket is felismertek. Az apolárosnak vélt szénfelület sav/bázis tulajdonságokat mutat, vizes szuszpenzióban képes eltolni a víz pH-ját. H. P. Böhm nevéhez füződik az ezért felelős sav/bázis tulajdonságú oxigéntartalmú szerves funkciós csoportok szelektív titrálásának kidolgozása ${ }^{3}$. Mára a módszert már rutinszerüen alkalmazzák a vizes közegü viselkedés vizsgálatakor, sőt potenciometrikus titrálással - kis számítástechnikai segítséggel - a felületi funkciós csoportok pKa eloszlása is meghatározhatón ${ }^{4,5}$.

A szén felületkémiájának jelentősége a 20. század nyolc-vanas éveiben a szénhordozós katalizátorok működési mechanizmusának vizsgálata kapcsán került igazán elötérbe. A fajlagos felület és a pórusméret-eloszlás ugyanis gyakran nem bizonyult elegendőnek a mechanizmusok megértéséhez. Az anyagtudományi vizsgálati módszerek, többek közt a röntgengerjesztéses fotoelektron spektroszkópia (XPS) elterjedése nagyban hozzájárult ahhoz, hogy a pórusos szenek felületkémiai viselkedését megértsük. Azonosították a sav/bázis tulajdonságokért felelős szénformákat és az oxigén tartalmú funkciós csoportokat, felismerték a turbosztratikus szénsíkokhoz tartozó $\pi$-elektronok bázikus jellegét elektronok szerepét (2. ábra). Ezen a nyomon haladva került elötérbe a szenek felületkémiai viselkedésének nemfém atomokkal történő hangolása is. Míg az oxigén heteroatom gyakorlatilag a síkok szélén helyezkedik el, a nitrogén pl. bizonyítottan beépülhet a szénatomok helyére is ${ }^{6,7}$.

Ez a tudás a kristályos szén nanorészecskék (fullerén, nanocső, grafén és származékaik) „intrinsic” tulajdonságaival (méret, alak, elektronszerkezet, stb.) összekapcsolva nagymértékben szélesíti azok alkalmazási lehetöségeit többek között az elektronikai iparban, a nanotechnológiában, a szenzorikában és a gyógyszerformálásban, hozzájárul biológiai hatásuk értelmezéséhez, stb. A felületkémiában keresendő a magyarázata a grafén részecskék pH-érzékeny ülepedési tulajdonságainak ${ }^{8}$, alakváltozásának ${ }^{9}, \mathrm{pH}$-val szabályozható fém nanorészecske megkötő képességének ${ }^{10}$. A szén nanorészecskék felületkémiájuktól és alakjuktól képesek befolyásolni reszponzív lágygél kompozitokban azok hőmérsékletváltozásra vagy IR besugárzásra adott válaszát is ${ }^{11,12}$.

A következőkben néhány további, ugyancsak a saját kutatási eredményeinkből vett példával illusztráljuk a szén felületkémiájának lehetőségét és szerepét néhány, anyagtudományi szempontból is releváns példán. 


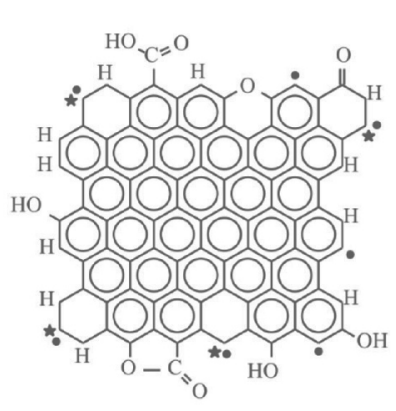

a

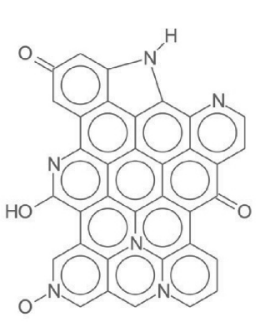

b

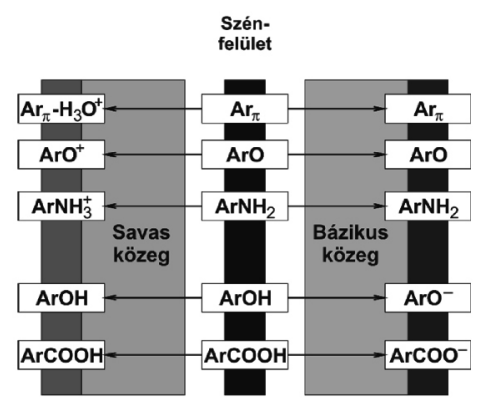

c

2. Ábra A szénfelületeken kialakuló O- (a) és N-tartalmú (b) funkciós csoportok, ill. azok viselkedése pH-függő körülmények között (c) ${ }^{6,7}$

\section{A szénfelület sav/bázis tulajdonságainak szerepe a $\mathrm{Cu}\left(\mathrm{NO}_{3}\right)_{2}+$ benzol-1,3,5-trikarbonsav reakcióban}

A szén aerogéleket különlegesen laza szerkezetüknek köszönhetően eredményesen használhatjuk társított anyagokban is.

Célunk a $\mathrm{Cu}\left(\mathrm{NO}_{3}\right)_{2}+$ benzol-1,3,5-trikarbonsav reakcióban pl. szolvotermikus körülmények között önszerveződéssel képződő, HKUST-1 fantázianéven is ismert fémorganikus térhálós vegyület laza szerkezetü szénhordozóba történő beágyazása volt (3. ábra).

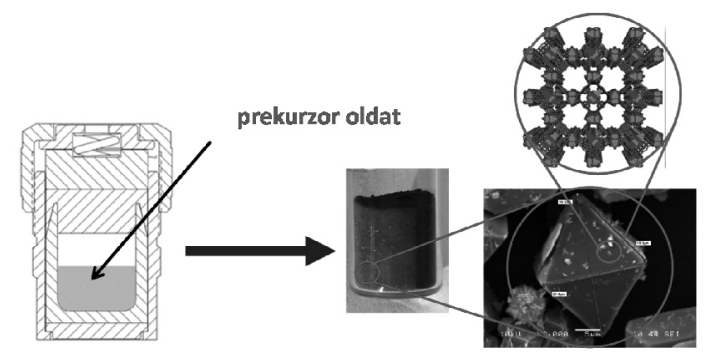

3. Ábra A fémorganikus térhálós vegyületet (metal organic framework, MOF) szolvotermikus eljárással (etanol-víz elegy, $80{ }^{\circ} \mathrm{C}, 24 \mathrm{~h}$ ) állítottuk elő ill. vittük fel a hordozóra

Korábban eredményesen állítottunk elő HKUST1@grafén-oxid monolit hibrideket szolvotermikus körülmények között (4. ábra). Az eljárást szén aerogéllel nem sikerült megismételnünk: minden esetben $\mathrm{Cu}_{2} \mathrm{O}$ kristályok képződtek a felületen (5a. ábra). A rezorcin-formaldehid szén aerogél bázikus tulajdonságú felülete ugyanis a víz - etanol biner elegyben végrehajtott szintézis során a réz redukciójához vezetett. Az így képződő szénhordozós finomeloszlású $\mathrm{Cu}_{2} \mathrm{O}$ kiváló katalizátornak bizonyult $\mathrm{A}^{3}$ csatolásos reakciókban ${ }^{13}$.
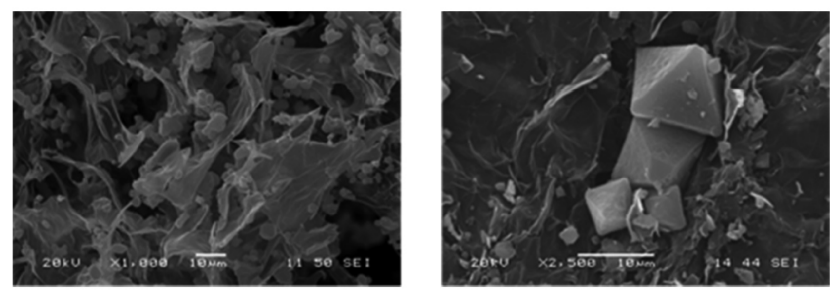

4. Ábra Grafén-oxid monolit kriogélbe ágyazott MOF pásztázó elektronmikroszkópos felvételei.

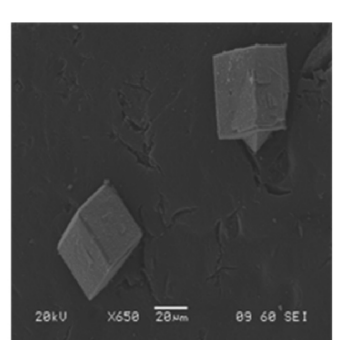

a

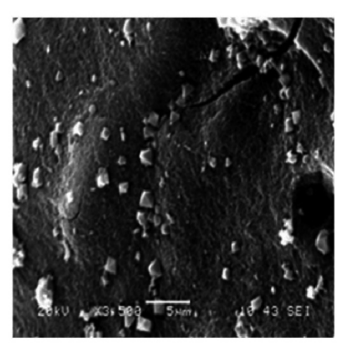

b
5. Ábra Bázikus (a) és b) savas (b) szén aerogél felületen képződő $\mathrm{Cu}_{2} \mathrm{O}$ ill. HKUST-1 pásztázó elektronmikroszkópos felvételei eltérő nagyításban

A HKUST-1@szén aerogél kompozit eredményes előállításához a szénfelületet először salétromsavas oxidációnak kellett alávetnünk (6. ábra). A grafén-oxidhoz hasonlóan savas funkciós csoportokat tartalmazó felületen a várt oktahedrális MOF kristályok képződtek (5.b ábra) ${ }^{13}$.

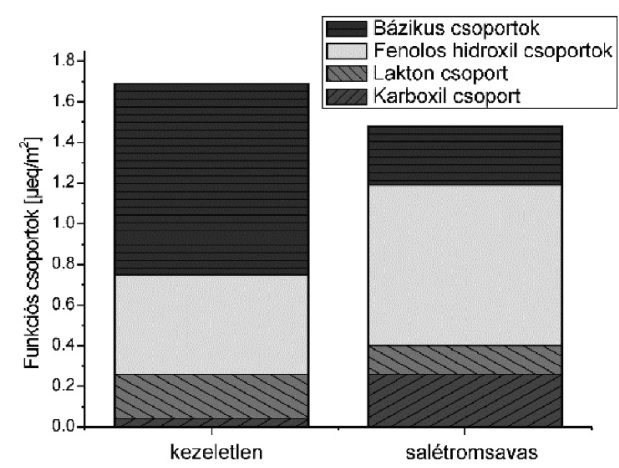

6. Ábra Az eredeti és a salétromsavval kezelt minta Böhm titrálásának eredménye. Az eredeti minta pH-ja 8,6-ról 5,9-re csökkent ${ }^{14}$

\section{Szén nanocsövek felületkémiájának hatása katalitikus aktivitásukra}

Propilénből kémiai gőzleválasztással előállított és kémiailag módosított (oxidált, O-CNT, ill. N-tartalmú, N-CNT) többfalú szén nanocsövek (MWCNT) felületi tulajdonságainak hatását vizsgáltuk hidrogénperoxid katalitikus bontása során ${ }^{15,16}$. Gázadszorpciós méréseink alapján a nanocsövek morfológiája gyakorlatilag azonosnak mondható ${ }^{17}$. A nanocsövek fajlagos felületét és XPS módszerrel meghatározott elemösszetételét az 1. táblázatban foglaltuk össze. 
1. Táblázat. A kiindulási, oxidált és N-tartalmú többfalú szén nanocsövek látszólagos fajlagos felülete és összetétele XPS módszerrel

\begin{tabular}{cccccccccc} 
& \multicolumn{3}{c}{ kiindulási állapot } & \multicolumn{5}{c}{ három ciklus után } \\
& $S_{\mathrm{BET}, \mathrm{N} 2}$ & $\mathrm{C}$ & $\mathrm{O}$ & $\mathrm{N}$ & $S_{\mathrm{BET} \mathrm{N} 2}$ & $\mathrm{C}$ & $\mathrm{O}$ & $\mathrm{N}$ \\
& $\mathrm{m}^{2} / \mathrm{g}$ & \multicolumn{2}{c}{ atomi \% } & & $\mathrm{m}^{2} / \mathrm{g}$ & \multicolumn{3}{c}{ atomi \% } \\
O-CNT & 141 & 95,5 & 4,5 & - & 135 & 91,2 & 8,8 & \\
N-CNT & 145 & 98,3 & 1,1 & 0,6 & 137 & 96,3 & 3,7 & n.d.
\end{tabular}

Az O- és N-tartalmú szén nanocsövek peroxid bontó katalitikus hatását vizes közegben vizsgálva (7. ábra), megállapítható, hogy a N-tartalmú nanocső a kis N-tartalom ellenére is lényegesen nagyobb peroxid-bontó aktivitást mutat. Az eltérő aktivitást magyarázza a peroxid bontás eltérő aktiválási energiája a kétfajta szén nanocső felületén: a 20-50 ${ }^{\circ} \mathrm{C}$ intervallumban 27,4 $\pm 3,2 \quad$ (O-CNT) és $15,4 \pm 2,8 \mathrm{~kJ} / \mathrm{mol}(\mathrm{N}-\mathrm{CNT})$ értéket határoztunk meg.

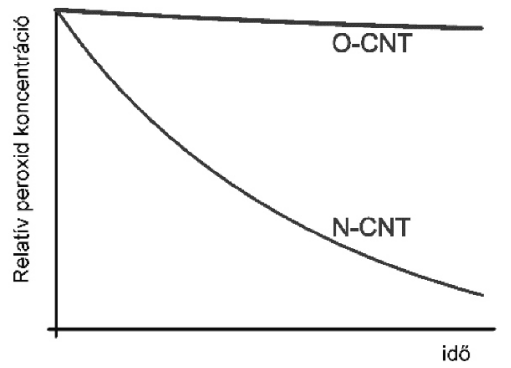

7. ábra Hidrogénperoxid katalitikus bontásának kinetikája $20{ }^{\circ} \mathrm{C}$-on $\mathrm{pH}=8$ vizes oldatban. O-CNT $\left(\left[\mathrm{H}_{2} \mathrm{O}_{2}\right]_{0}=2,35 \mathrm{~mol} / \mathrm{l}\right) ; \mathrm{N}-\mathrm{CNT}$ $\left(\left[\mathrm{H}_{2} \mathrm{O}_{2}\right]_{0}=0,235 \mathrm{~mol} / \mathrm{l}\right){ }^{16}$

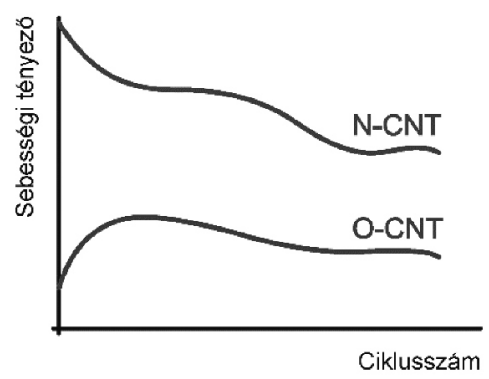

8. ábra A többfalú szén nanocsövek katalitikus aktivitásának változása a használat során $20{ }^{\circ} \mathrm{C}$-on. O-CNT $\left(\left[\mathrm{H}_{2} \mathrm{O}_{2}\right]_{0}=1,47 \mathrm{~mol} / \mathrm{l}, \mathrm{pH}=6.9\right)$; $\mathrm{N}-\mathrm{CNT}\left(\left[\mathrm{H}_{2} \mathrm{O}_{2}\right]_{0}=0,235 \mathrm{~mol} / 1, \mathrm{pH}=8,0\right) .{ }^{16}$

Mindkét nanocső katalitikus aktivitása változik a ciklusok számának növekedésével. A N-tartalmú szén nanocsövek katalitikus aktivitása a reakció elörehaladtával csökken, míg ez a hatás lényegesen kisebb az O-CNT esetén. A 3. ciklus utáni XPS eredmények a N-funkciós csoportok lassú deaktiválódására utalnak: a N-tartalom a detektálási limit alá csökken. A későbbi stabilizálódás, ill. az újabb aktivitásvesztés mindkét nanocső esetén - az XPS és hőmérsékletprogramozott bomlási vizsgálatok (TPD) alapján - egyértelmúen a felületi O-tartalmú csoportok komplex átalakulásaival kapcsolatos.

\section{Köszönetnyilvánítás}

Köszönettel tartozom a Felületkémiai Csoportban korábban és jelenleg dolgozó hallgatóimnak, akiknek lelkiismeretes és kreatív munkája nélkül nem születtek volna meg ezek az eredmények. A témában folyó kutatásokat jelenleg az OTKA K109558 és egy VEKOP pályázat segíti. A VEKOP-2.3.2-162017-00013 projekt keretében folyó kutatásokat az Európai Unió és Magyarország Kormánya támogatja az Európai Regionális Fejlesztési Alap hozzájárulásával.

\section{Hivatkozások}

1 Schay, G.; Nagy, L. Gy.; Szekrényesy, T. Periodica Polytechnica Chemical Engineering. 1960, 4(2), 95-117.

2. Schay, G.; Nagy, L. J. Chim. Phys. 1961, 58, 149-158. https://doi.org/10.1051/jcp/1961580149

3. Böhm, H. P.; Diehl, E.; Heck, W.; Sappok, R. Angew. Chem. Int. Ed. Engl. 1964, 3(10), 669-677 https://doi.org/10.1002/anie.196406691

4. László, K.; Tombácz, E.; Carbon. 2001, 39(8), 1217-1228. https://doi.org/10.1016/S0008-6223(00)00245-1

5. László, K.; Tombácz, E.; Novák, CS. Colloids and Surfaces A. 2007, 306(1-3), 95-101. https://doi.org/10.1016/j.colsurfa.2007.03.057

6. Radovic, L. R.; Moreno-Castilla, C.; Rivera-Utrilla, J. In Chemistry and Physics of Carbon: A Series of Advances; Radovic, L. R., Ed.; Marcel Dekker, Inc.: New York, 2001; Vol. 27, pp 227-406.

7. Pels, J. R.; Kapteijn, F.; Moulijn, J. A.; Zhu, Q.; Thomas, K. M. Carbon. 1995, 33, 1641-1653. https://doi.org/10.1016/0008-6223(95)00154-6

8. Szabó, T.; Tombácz, E.; Illés, E.; Dékány, I. Carbon. 2006, 44, 537-545. https://doi.org/10.1016/j.carbon.2005.08.005

9. Whitby, R. L. D.; Gun'ko, V. M.; Korobeinyk, A.; Busquets, R.; Cundy A. B.; László, K.; Skubiszewska-Zięba, J.; Leboda, R.; Tombácz, E.; Tóth, I. Y.; Kovács, K.; Mikhalovsky, S. V. ACS Nano. 2012, 6(5), 3967-3973. https://doi.org/10.1021/nn3002278

10. Whitby, R. L. D.; Korobeinyk, A.; Gun'ko, V. M.; László, K.; Skubiszewska-Zięba, J.; Leboda, R.; Tombácz, E.; Tóth, I. Y.; Kovács, K.; Mikhalovsky, S. V. Chemical Communications. 2011, 47, 9645-9647. https://doi.org/10.1039/c1cc13725e

11. Berke, B.; Sós, L.; Bérczes, V.; Domján, A.; Porcar, L.; Czakkel, O.; László, K. European Polymer Journal. 2017, 93, 717-725.

https://doi.org/10.1016/j.eurpolymj.2017.02.046

12. Manek, E.; Berke, B.; Miklósi, N.; Sajbán, M.; Domán, A.; Fukuda, T.; Czakkel, O.; László, K. Express Polymer Letters 2016, 10(8), 710-720. https://doi.org/10.3144/expresspolymlett.2016.64

13. Nagy, B.; Nichele, L. P.; Srankó, D.; Hell, Z.; Madarász, J.; László, K. Effect of carbon surface chemistry on the $\mathrm{Cu}^{2+}+$ benzene-1,3,5-tricarboxylic acid reaction. The World Conference on Carbon, 2016. július 10-15, State College, PA, USA. CD ROM of Extended abstracts.

14. Barbély, G.; BSc Dissertation, Budapest University of Technology and Economics, 2014.

15. Voitko, K. V.; Whitby, R. L. D.; Gun'ko, V. M.; Bakalinska, O. M.; Kartel, M. T.; László, K.; Cundy, A. B.; Mikhalovsky, S. V. J. Colloid Interface Sci. 2011, 361(1), 129-136. https://doi.org/10.1016/j.jcis.2011.05.048

16. Voitko, K.; Tóth, A.; Demianenko, E.; Dobos, G.; Berke, B.; Bakalinska, O.; Grebenyuk, A.; Tombácz, E.; Kuts, V.; Tarasenko, Y.; Kartel, M.; László, K. Journal of Colloid and Interface Science. 2015, 437, 283-290. https://doi.org/10.1016/j.jcis.2014.09.045

17. Tóth, A.; Voitko, K. V.; Bakalinska, O.; Prykhod'ko, G. P.; Bertóti, I.; Gun'ko, V. M.; László K. Carbon. 2012, 50(2), 577-585. https://doi.org/10.1016/j.carbon.2011.09.016 
Role of carbon surface chemistry in materials science.

From Schay - Nagy isotherm equation to tailored graphene oxide.

In spite of their hydrophobic character porous carbons have been considered as general adsorbents due to their sophisticated microporous character. Although the existence and relevance of polar/nonpolar sites on porous carbon surfaces were observed already in the 1960s (Figure 1), it was in the late $80 \mathrm{~s}$ when the importance of carbon surface chemistry was first analyzed in depth, as neither the surface area nor the pore structure were sufficient to explain many of the behaviours of carbon-supported catalysts. Chemical treatment, as well as impregnation or doping techniques, are often used to deliberately enhance the performance of carbon materials. Here we focus on carbons modified with $\mathrm{O}$ and $\mathrm{N}$ heteroatoms. Besides the delocalized electrons the surface chemical groups including these heteroatoms were found also responsible for the acid/base behaviour of the carbons in aqueous solutions (Figure 2).

This information also efficiently widens the potential of crystalline carbon nanoparticles (fullerenes, nanotubes, graphene and their derivatives) and their composites, in various applications, e.g., as catalysts, (electro)catalytic devices, drug release vehicles, sensors, etc.

For this communication, various forms of carbon materials with well-characterized $\mathrm{O}$ and $\mathrm{N}$ content were selected as examples to illustrate the relevance of surface chemistry in their performance. As a first example, it was shown that the solvothermal chemical reaction between $\mathrm{Cu}\left(\mathrm{NO}_{3}\right)_{2}$ and benzene-1,3,5tricarboxylic acid in the presence of a high surface area porous carbon aerogel may either yield $\mathrm{Cu}_{2} \mathrm{O}$ or copper benzene-1,3,5-tricarboxylate (HKUST-1) in case of basic or acidic carbon surface properties, respectively (Figure 3). Analysis of $\mathrm{N}_{2}$ adsorption/desorption isotherms showed that the oxidative surface treatment prior the MOF synthesis resulted in no significant change in the surface area and the pore structure of the carbon material but the surface chemistry. However, the morphology of the crystals that develop on the surface was different both in colour and in shape. Tetragonal HKUST-1 crystals were only obtained on the acidic carbon aqueous (Figure 4b). By contrast, on the surface of the basic carbon cubic $\mathrm{Cu}_{2} \mathrm{O}$ crystals formed selectively (Figure 4a). The difference in the chemical processes occurring on the surface is attributed to the different surface chemistry of the carbon matrices. Enrichment of $\mathrm{Cu}^{2+}$ ions on the acidic surface initiates the self-assembly of the HKUST-1 network. The basic surface may catalyse the reduction of the $\mathrm{Cu}^{2+}$, probably also with mediation by the ethanol co-solvent. The finely dispersed cuprous oxide proved to be an excellent selective catalyst in two alkyne-amine-aldehyde $\left(\mathrm{A}^{3}\right)$ reactions.

Another example compares the hydrogen peroxide decomposition activity of $\mathrm{O}$ and $\mathrm{N}$ doped multiwalled carbon nanotubes (MWCNTs). The oxidized sample showed a low catalytic activity with an approximately linearly decreasing kinetic curve different from that of the nitrogen-doped (N-CNT) tubes (Figure 7). The oxidation introduced new surface functional groups into the edges and defects into the O-CNT sample, modifying at the same time the density distribution of the delocalized electrons. Moreover, as electron donor/acceptor sites are strong free radical scavengers, the free radicals from hydrogen peroxide may adsorb and become deactivated on the surface of the MWCNT (Figure 7). The positive effect of the nitrogen atoms on the catalytic properties of the CNTs in electron transfer reactions could be explained by a decrease in the band gap of the N-CNT. This produces higher electron mobility and lowers the value of the electron work function at the N-CNT - hydrogen peroxide interface. For quantitative assessment, and comparison of the activity of the O-CNT and N-CNT samples, both the rate constants and the activation energies were determined. The latter was found $27.4 \pm 3.2$ and $15.4 \pm 2.8 \mathrm{~kJ} / \mathrm{mol}$ for $\mathrm{O}-\mathrm{CNT}$ and $\mathrm{N}-\mathrm{CNT}$, respectively. The operational stability of the CNTs was examined over 10 cycles ( $30 \mathrm{~min}$ each) at $20^{\circ} \mathrm{C}$. During the catalytic peroxide decomposition the catalytic activity changes with the cycles in both cases (Figure 8). That implies that these nanotubes are not passive catalysts but their surface composition changes during the reactions which also affect their catalytic performance.

Further examples were reported by our group on the effect of $\mathrm{pH}$ on the shape of graphene oxide nanoparticles as fillers 9,10 . The shape and surface chemistry of carbon nanoparticles influences the thermal and IR responsivity of smart soft hydrogels when filled with nanotubes or graphene derivatives, respectively, already in low concentration ${ }^{11,12}$. 